Plant Tissue Cult. \& Biotech. 30(1): 161-166, 2020 (June)

@Bangladesh Assoc. for Plant Tissue Culture \& Biotechnology

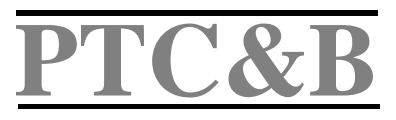

\title{
Conservation of an Endangered Medicinal Tree Species Taxus wallichian through Callus Induction and Shoot Regeneration
}

\author{
Nadia Gul, Sofia Baig', Raza Ahmed, Irum Shahzadi, Iftikhar Zaman², \\ Mohammad Maroof Shah and Ayesha Baig*
}

Biotechnology Department, COMSATS University Islamabad, Abbottabad Campus, Pakistan

Key words: Callus Induction, Shoot regeneration, Taxus wallichiana

Callus production and regeneration using leaf and internode as explant was carried out at different combinations of plant growth regulators. Taxu wallichiana leaf explant initiated significant callus on MS CIMк1 $(1.7 \mathrm{mg} / 2,4$-D and $1.0 \mathrm{mg} \Lambda \mathrm{Kn})$ with $4.0 \mathrm{~mm}^{2}$ callus area after 45 days. Similarly MS medium $\mathrm{CIM}_{\mathrm{B} 1}-\mathrm{CIM}_{\mathrm{B} 4}(1.2,1.5,1.7$ and $2.0 \mathrm{mg} A$ of BAP with $2.0 \mathrm{mg} \lambda$ of 2,4-D) showed equally significant callus induction but with less callus area of $3.0 \mathrm{~mm}^{2}$ compared to 2,4-D and $\mathrm{Kn}$. For regeneration, shooting was optimized with MS SIM IA1-SIM IAз (1.5, 2.5, $3.5 \mathrm{mg} /$ IAA and BAP $2.0 \mathrm{mg} \Lambda$ ). Maximum shoot length $(1.5 \mathrm{~mm})$ was obtained after 45 days from internode. However, there was no root formation in the above mentioned combinations.

Taxus wallichiana, a long lived evergreen tree species is known as Himalayan Yew (Poudel et al. 2012). It belongs to Taxaceae of genus Taxus and occurs at an altitude of about 1800 - $4400 \mathrm{~m}$ (Shaheen et al. 2015). Taxu wallichiana occurs in Asia including China, India, Iran, Pakistan, Korea Nepal, Philippines and Taiwan. It is also found in Thandiani, Dhongagali, Nathiagali, and the Himalayas region of Pakistan (Poudel et al. 2012). Taxus wallichiana is famous for its anti-cancerous, anti-convolunary and immuneregulatory effects (Dang et al. 2017). It is traditionally used for treatment of high fever, inflammation, tuberculosis and diarrhea (Juyal et al. 2014). It possesses antibacterial, antifungal and antioxidant properties (Adhikari et al. 2017).

Taxus wallichiana has been commercialized due to its immense ethno-botanical and medicinal properties (Dang et al. 2017). The leaves and bark have been explicitly used for the extraction of Taxol (Cusido et al. 2002). Taxol has unique property of preventing the growth of cancerous cells (Zhang et al. 2005). Plant tissue culture technique can be used to save this endangered tree species through micropropagation and callus culture.

*Author for correspondence: <ayeshabaig@cuiatd.edu.pk>. ${ }^{1}$ Environmental Sciences, IESE National University for Sciences and Technology (NUST) Islamabad, Pakistan. ${ }^{2}$ Abbottabad Wildlife Division Khyber Pakhtunkhawa, Pakistan.

DOI: https://doi.org/10.3329/ptcb.v30i1.47801 
(Datta et al. 2006). Callus culture cannot only result in plantlet production but it can also be used to enhance medicinal properties of such an important plant species. A large number of phytochemicals including taxenes, diterpenes, flavanoids, lignans and steroids derivatives have been isolated from several species of Taxus including Taxus wallichiana (Dand et al. 2017). In this study, Taxus wallichiana callus induction and shoot regeneration was optimized using different concentrations of growth regulators (Hussain et al. 2013) including cytokinin such as BAP and $\mathrm{Kn}$ and auxin such as 2,4-D and IAA.

Taxus wallichiana was collected from Dhongagali, Pakistan. Current work on regeneration and callus formation was conducted at Genetic Engineering laboratory of COMSATS University, Abbottabad, Pakistan. MS was prepared with $15 \mathrm{~g}$ of sucrose along with $2.2 \mathrm{~g}$ of MS powder (Murashige and Skoog 1962). Ph was adjusted to 5.8 and $4 \mathrm{~g}$ of agar was added to it. The medium was autoclaved at $120^{\circ} \mathrm{C} / 15 \mathrm{psi}$. Explants including leaf and internode were sterilized with $0.1 \% \mathrm{MgCl}_{2}$ and washed three times with distilled water. Later, explant was placed on different callus induction medium (CIM) and shoot induction medium (SIM; Table 1) under $8 \mathrm{hrs}$ dark and $16 \mathrm{hrs}$ light at $28^{\circ} \mathrm{C}$ for callus growth and regeneration.

Table 1. Various concentrations of plant growth regulators including 2,4-D, NAA, IAA, BAP and $\mathrm{Kn}$ used for callus induction and regeneration.

\begin{tabular}{|c|c|c|}
\hline Callus induction media & 2,4-D (mg $\Lambda)$ & $\mathrm{Kn}(\mathrm{mg} /)$ \\
\hline СІМк1 & 1.5 & 1.0 \\
\hline СІМк2 & 1.5 & 1.5 \\
\hline СІМкз & 1.7 & 1.0 \\
\hline СІМк4 & 1.7 & 1.5 \\
\hline СІМк5 & 2.0 & 1.0 \\
\hline СІМк6 & 2.0 & 1.5 \\
\hline Callus induction media & 2, 4-D (mg $\Lambda)$ & $\mathrm{BAP}(\mathrm{mg} \Lambda)$ \\
\hline CIMв1 & 2.0 & 1.2 \\
\hline СІМв2 & 2.0 & 1.5 \\
\hline СІМвз & 2.0 & 1.7 \\
\hline CIMв4 & 2.0 & 2.0 \\
\hline Shoot induction media & $\operatorname{BAP}(\mathrm{mg} /)$ & IAA $(\mathrm{mg} /)$ \\
\hline SIMIA1 & 2.0 & 1.5 \\
\hline SIMIA2 & 2.0 & 2.5 \\
\hline SIMIA3 & 2.0 & 3.5 \\
\hline
\end{tabular}

Data for Taxus wallichiana callus induction was collected after 15, 30 and 45 days by measuring callus area. In case of shoot regeneration, data were recorded for shoot length and number of leaves after 15, 30 and 45 days of culturing internode. Statistical analysis was performed based on ANOVA and the mean values were compared by performing LSD test using R Program (R Core Team 2018).

Callus appeared on MS with 2, 4-D and Kn from Taxus wallichiana leaf explant. Significantly high callus formation was recorded for СІМкз $(1.7: 1.0 \mathrm{mg} /)$ with 2,4-D and 
Kn after 15 days (Fig. 1, Table 2). Since optimal callus induction is important for metabolites production (Sarmadi et al. 2018), the effects of the different concentrations of 2,4-D and Kn on callus formation was determined after 15, 30 and 45 days. After 30 days, СІМкз $(1.5: 1.0 \mathrm{mg} /)$ with 2,4-D: Kn was found to be most significant treatment along with СІМкб $(2.0: 1.5 \mathrm{mg} \Lambda)$ based on statistical analysis. СІМкз was the only treatment that showed best callus induction 45 days after culturing with $4.51 \mathrm{~mm}^{2}$ callus area. Optimal callus formation was also achieved in MS with 2,4-D (2.0 mg $)$ : $\mathrm{Kn}(0.5 \mathrm{mg} /)$ from zygotic embryo and with 2,4-D, activated charcoal (2.0: $1.5 \mathrm{mg} \Lambda$ ) from stem explant (Datta et al. 2006, Hussain et al. 2011). In another study callus formation with 2, 4-D and Kn was reported on B5 instead of MS (Jha et al. 1998). Present data however suggest СІМкз $(1.7: 1.0 \mathrm{mg} /)$ with 2,4-D and $\mathrm{Kn}$ as optimal condition for callus induction with callus area $4.0 \mathrm{~mm}^{2}$ (Fig. 1 and Table 2 ).


Fig. 1. In vitro grown Taxus wallichiana leaflets showing callus formation at different concs. of 2, 4-D and Kn. (A C) СІМк1 after 15, 30 and 45 days of culturing (D - F) СІМк6 after 15, 30 and 45 days of culturing, (G - I) СІМкз with 15, 30 and 45 days after callus formation. 
Table 2. Statistical analysis of data recorded after 15, 30 and 45 days of Taxus wallichiana callus culture with 2, 4-D and Kn.

\begin{tabular}{llllll}
\hline $\begin{array}{l}\text { Sl. } \\
\text { no. }\end{array}$ & Treatment & $\begin{array}{l}2,4-\mathrm{D}: \mathrm{Kn} \\
(\mathrm{mg} A)\end{array}$ & $\begin{array}{l}\text { Callus area }: \mathrm{mm}^{2} \\
(\mathrm{~A})\end{array}$ & $\begin{array}{l}\text { Callus area }: \mathrm{mm}^{2} \\
(\mathrm{~B})\end{array}$ & $\begin{array}{l}\text { Callus area }: \mathrm{mm}^{2} \\
(\mathrm{C})\end{array}$ \\
\hline 1. & CIMK1 & $1.5: 1.0$ & $0.86 \pm 0.5^{\mathrm{b}}$ & $1.78 \pm 1.0^{\mathrm{ab}}$ & $3.75 \pm 1.4^{\mathrm{ab}}$ \\
2 & CIMK2 & $1.5: 1.5$ & $0.89 \pm 0.7^{\mathrm{ab}}$ & $1.96 \pm 1.0^{\mathrm{ab}}$ & $3.47 \pm 1.4^{\mathrm{ab}}$ \\
3. & CIMK3 & $1.7: 1.0$ & $1.52 \pm 0.2^{\mathrm{a}}$ & $2.60 \pm 0.6^{\mathrm{a}}$ & $4.52 \pm 0.7^{\mathrm{a}}$ \\
4. & CIMK4 & $1.7: 1.5$ & $0.35 \pm 0.2^{\mathrm{bc}}$ & $1.07 \pm 0.4^{\mathrm{b}}$ & $3.20 \pm 1.4^{\mathrm{ab}}$ \\
5. & CIMK5 & $2.0: 1.0$ & $0.24 \pm 0.1^{\mathrm{c}}$ & $0.98 \pm 0.4^{\mathrm{b}}$ & $2.24 \pm 0.6^{\mathrm{b}}$ \\
6. & CIMк6 & $2.0: 1.5$ & $1.46 \pm 0.4^{\mathrm{a}}$ & $2.65 \pm 0.4^{\mathrm{a}}$ & $3.53 \pm 1.5^{\mathrm{ab}}$ \\
\hline
\end{tabular}

Data are represented as means \pm SE from 10 replicates. Different letters within each column represent significant differences between treatments at $\mathrm{p} \leq 0.05$ LSD. (A) СІМкз and СІМк6 were the most significant treatments for callus induction after 15 days of culturing. (B) СІМкз and СІМк6 with 2,4-D: Kn gave significant result 30 days after culturing. (C) СІМкз was found to be most significant for callus formation 45 days after culturing.

Different concentrations of 2, 4-D with BAP were used to determine their effect on callus formation (Table 1). Significantly result was recorded with СІМв2 $(2.0: 1.5 \mathrm{mg} \Lambda)$ for callus area based on data recorded after 15 days of culturing. Similarly $\mathrm{CIMB}_{2}$ showed significant result after 30 days of culturing. СІМв1, СІМв2, СІМвз and $\mathrm{CIM}_{\mathrm{B} 4}$ were all found to be equally significant for callus induction for 2, 4-D and BAP after 45 days of culturing (Table 3). BAP and 2, 4-D also showed callus formation at different concentrations in Taxus baccata. Thus different combinations of cytokinin and auxin were used for callus formation from leaf and stem explant (Ashrafi et al. 2010).

Table 3. Statistical analysis of data recorded after 15, 30 and 45 days of Taxu swallichiana callus culture with 2, 4-D and BAP.

\begin{tabular}{llllll}
\hline $\begin{array}{l}\text { S1. } \\
\text { no. }\end{array}$ & Treatment & $\begin{array}{l}2,4-\mathrm{D}: \mathrm{BAP} \\
(\mathrm{mg} /)\end{array}$ & $\begin{array}{l}\text { Callus area : } \\
\mathrm{mm}^{2}(\mathrm{~A})\end{array}$ & $\begin{array}{l}\text { Callus area : } \\
\mathrm{mm}^{2}(\mathrm{~B})\end{array}$ & $\begin{array}{l}\text { Callus area : } \\
\mathrm{mm}^{2}(\mathrm{C})\end{array}$ \\
\hline 1. & $\mathrm{CIM}_{\mathrm{B} 1}$ & $2.0: 1.2$ & $0.27 \pm 0.1^{\mathrm{b}}$ & $1.13 \pm 0.4^{\mathrm{b}}$ & $2.32 \pm 0.7^{\mathrm{a}}$ \\
2. & $\mathrm{CIM}_{\mathrm{B} 2}$ & $2.0: 1.5$ & $0.61 \pm 0.1^{\mathrm{a}}$ & $1.66 \pm 0.3^{\mathrm{a}}$ & $2.98 \pm 0.6^{\mathrm{a}}$ \\
3. & $\mathrm{CIM}_{\mathrm{B} 3}$ & $2.0: 1.7$ & $0.33 \pm 0.1^{\mathrm{b}}$ & $1.04 \pm 0.2^{\mathrm{b}}$ & $2.30 \pm 0.2^{\mathrm{a}}$ \\
4. & $\mathrm{CIM}_{\mathrm{B} 4}$ & $2.0: 2.0$ & $0.41 \pm 0.2^{\mathrm{ab}}$ & $1.26 \pm 0.4^{\mathrm{ab}}$ & $2.89 \pm 0.5^{\mathrm{a}}$ \\
\hline
\end{tabular}

Data are represented as means \pm SE from 10 replicates. Different letters within the same column indicate significant differences between treatments at $\mathrm{p} \leq 0.05$ LSD. (A) СІМв2 was found to be most significant for callus area. (B)СІМв2 showed significantly callus formation 30 days after culturing. (C) СІМв1, СІМв2, СІМв3 and СІМв4 were all found to be equally significant for callus induction after 45 days. 
Table 4. Statistical analysis of data recorded for Taxus wallichiana shoot formation with BAP and IAA.

\begin{tabular}{llllll}
\hline $\begin{array}{l}\text { Sl. N } \\
\text { no. }\end{array}$ & Treatment & $\begin{array}{l}\text { BAP : IAA } \\
(\mathrm{mg} \Lambda)\end{array}$ & $\begin{array}{l}\text { Shoot length } \\
\mathrm{mm}(\mathrm{A})\end{array}$ & $\begin{array}{l}\text { Shoot length } \\
\mathrm{mm}(\mathrm{B})\end{array}$ & $\begin{array}{l}\text { Shoot length } \\
\mathrm{mm}(\mathrm{C})\end{array}$ \\
\hline 1. & SIMIA1 & $2.0: 1.5$ & $0.68 \pm 0.2^{\mathrm{a}}$ & $1.02 \pm 0.2^{\mathrm{a}}$ & $1.30 \pm 0.1^{\mathrm{a}}$ \\
2. & SIMIA2 & $2.0: 2.5$ & $0.80 \pm 0.3^{\mathrm{a}}$ & $1.15 \pm 0.3^{\mathrm{a}}$ & $1.43 \pm 0.2^{\mathrm{a}}$ \\
3. & SIMIA3 & $2.0: 3.5$ & $0.48 \pm 0.3^{\mathrm{a}}$ & $0.48 \pm 0.2^{\mathrm{b}}$ & $0.82 \pm 0.4^{\mathrm{b}}$ \\
\hline
\end{tabular}

Data are represented as means \pm SE from 10 replicates. Different letters within the same column indicate significant differences between treatments at $\mathrm{p} \leq 0.05$ LSD. (A) SIMIA1, SIMIA2 and SIMIA3 15 days after internode culturing. (B) SIMIA1, SIMIA2 and SIMIA3 30 days after culturing. (C) Data recorded after 45 days of culturing with SIMIA1, SIMIA2 and SIMIA3.

Table 5. Statistical analysis of data recorded for Taxus wallichiana shoot and leaf formation with BAP and IAA.

\begin{tabular}{lllccc}
\hline $\begin{array}{l}\text { Sl. } \\
\text { no. }\end{array}$ & Treatment & $\begin{array}{l}\text { BAP:IAA } \\
(\mathrm{mg} /)\end{array}$ & $\begin{array}{c}\text { No of leaves } \\
(\mathrm{A})\end{array}$ & $\begin{array}{r}\text { No of leaves } \\
(\mathrm{B})\end{array}$ & $\begin{array}{c}\text { No of leaves } \\
(\mathrm{C})\end{array}$ \\
\hline 1. & SIMIA1 & $2.0: 1.5$ & $3.14 \pm 0.8^{\mathrm{a}}$ & $4.42 \pm 0.5^{\mathrm{a}}$ & $6.14 \pm 1.0^{\mathrm{a}}$ \\
2. & SIMIA2 & $2.0: 2.5$ & $4.16 \pm 0.7^{\mathrm{a}}$ & $5.33 \pm 0.8^{\mathrm{a}}$ & $6.83 \pm 0.7^{\mathrm{a}}$ \\
3. & SIMIA3 & $2.0: 3.5$ & $3.40 \pm 1.0^{\mathrm{a}}$ & $5.00 \pm 1.0^{\mathrm{a}}$ & $6.00 \pm 0.7^{\mathrm{a}}$ \\
\hline
\end{tabular}

Data are represented as means \pm standard errors from 10 replicates. Different letters within the same column indicate significant differences between treatments at $p \leq 0.05$ LSD (A) SIMIA1, SIMIA2 and SIMIA3 15 days after internode culturing. (B) SIMIA1, SIMIA2 and SIMIA3 30 days after culturing. (C) Data recorded after 45 days of culturing with SIMIA1, SIMIA2 and SIMIA3
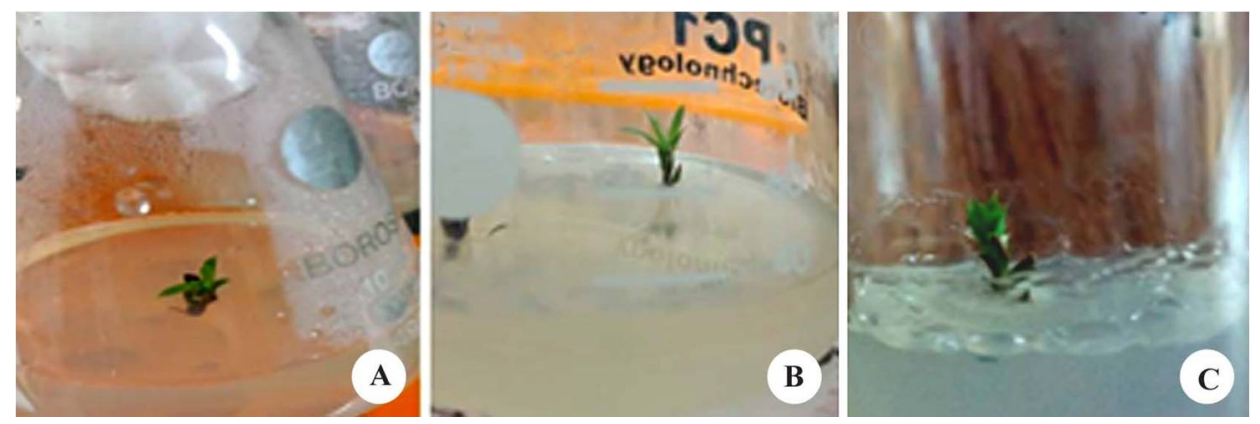

Fig. 2. In vitro culture of Taxu wallichiana node with shoot formation at various concentrations of BAP and IAA. (A) SIMiA1 after 45 days, (B) SIMIA2 after 45 days, (C) SIMIA3 after 45 days of shoot and leaf formation.

For regeneration, IAA $(1.5,2.5,3.5 \mathrm{mg} \Lambda)$ was used in combination with BAP $(2.0$ $\mathrm{mg}$ A). Data recorded after 15, 30 and 45 days of culturing (Fig. 2) showed shoot regeneration on shoot induction media (SIMIA1-SIMIA3) for all three treatments (Tables 4 and 5). No rooting was observed with different concentrations of IAA and BAP used. 
Taxus wallichiana showed rooting on MS with BAP, IBA and IAA (Hussain et al. 2011), however different sources of explants may be the reason for no rooting in this study. 2,4D with BAP on WP medium also showed Taxu wallichiana regeneration (Datta et al. 2006). This indicates that the composition of medium has important role in organogenesis and micropropagation.

\section{References}

Adhikari P and Pandey A (2017) Taxus wallichianazucc (Himalayan Yew) in Antimicrobial Perspective. Advances in Biotechnol. and Microbiol. 4(5): 555-650.

Ashrafi S, Mofid MR, Otroshi M, Ebrahimi M and Khosroshahli M (2010) Effect of plant growth regulators on the callogenesis and Taxol production in cell of suspension of Taxu sbaccata. Trakia J. Sci. 8(2): 36-43.

Cusidó RM, Palazon J, Bonfill M, Navia-Osorio A, Morales C and Piñol MT (2002) Improved paclitaxel and baccatin III production in suspension cultures of Taxus media. Biotechnol. Progress. 18: 418-423.

Dang PH, Nguyen HX, Duong TTT, Tran TKT, Nguyen PT, Vu TKT and Awale S (2017) A glucosidase inhibitory and cytotoxic taxanediterpenoids from the stem bark of Taxus wallichiana. J. of Natural Prod. 80: 1087-1095.

Datta MM, Majumder A and Jha S (2006) Organogenesis and plant regeneration in Taxus wallichiana (Zucc). Plant Cell Rep. 25: 11-18.

Hussain A, Qarshi IA, Nazir H, Ullah I, Rashi M and Shinwari ZK (2013) In vitro callogenesis and organogenesis in Taxus wallichiana ZUCC, The Himalayan Yew. Pak. J. Bot. 45: 1755-1759.

Jha S, Sanyal D, Ghosh B and Jha TB (1998) Improved taxol yield in cell suspension culture of Taxus wallichiana (Himalayan yew). Planta Med. 64: 270-272.

Juyal D, Thawani V, Thaledi S and Joshi M (2014) Ethnomedical properties of Taxus wallichiana ZUCcC (Himalayan Yew). J. Tradition Complement. Medi. 4(3): 159-161.

Murashige T and Skoog F (1962) A revised medium for rapid growth and bio assays with tobacco tissue cultures. Physiol. Plantarum.15: 473-497.

Poudel RC, Möller M, Gao LM, Ahrends A, Baral SR, Liu J, Thomas P and Li DZ (2012) Using morphological, molecular and climatic data to delimitate Yews along the Hindu Kush Himalaya and Adjacent Regions. PLOS ONE. 7(10): e46873.

R Core Team (2018) R: A language and environment for statistical computing Vienna, Austria.

Sarmadi M, Naser K N, Palazón J, GhassempourA and Mirjalili MH (2018) The effects of salicylic acid and glucose on biochemical traits and taxane production in a Taxus baccata callus culture. Plant Physiol. and Biochem. 132: 271-280.

Shaheen H, Sarwar R, Firdous SS, Dar MEI, Ullah Z and Khan SM (2015) Distribution and structure of conifers with special emphasis on Taxus baccata in moist temperate forests of Kashmir Himalayas. Pak. J. Bot. 47: 71-76.

Zhang B, Maiti A, Shively S, Lakhani F, Mcdonald Jones G, Bruce J and Toleikis PM (2005) Microtubule-binding drugs offset tau sequestration by stabilizing microtubules and reversing fast axonal transport deficits in a tauopathy model. Proceed. National Academy of Sci. 102: 227-231.

(Manuscript received on 30 December, 2019; revised on 7 May, 2020) 